\title{
First record of Duplachionaspis divergens (Green, 1899) (Hemiptera: Diaspididae) in forage grasses in Brazil
}

\author{
Fabricia Z. V. Torres ${ }^{1 \pm=(\infty)}$, José Raul Valério ${ }^{1 \oplus}$, Renata do N. Santos ${ }^{2 \oplus}$, Bruno B. Amaral ${ }^{1 \oplus}$, \\ Vera Regina dos S. Wolff ${ }^{3(0)}$
}

${ }^{1}$ Embrapa Gado de Corte, Campo Grande, Mato Grosso do Sul, Brazil. ${ }^{2}$ Universidade Católica Dom Bosco, Campo Grande, Mato Grosso do Sul, Brazil. ${ }^{3}$ Secretaria Estadual de Agricultura, Pecuária e Desenvolvimento Rural, Departamento de Diagnóstico e Pesquisa Agropecuária, Campo Grande, Mato Grosso do Sul, Brazil.

拝=-Corresponding author: fabricia.torres@embrapa.br

Edited by: Sandra Maria M. Rodrigues

Received: February 12, 2020. Accepted: March 03, 2020. Published: March 19, 2021.

\begin{abstract}
The purpose of this note is to report the first record of Duplachionaspis divergens (Green, 1899) (Hemiptera: Diaspididae) in forage grasses in Brazil. Specimens of this armored scale were found in heavily degraded pastures, with yellowish and dry clumps of Ipyporã grass, a Urochloa hybrid. Previously, this species had been reported in Brazil only in sugarcane under greenhouse conditions. Its presence in forage grasses has caused visibly significant damage. The extent of the consequent economic losses has yet to be estimated.
\end{abstract}

Keywords: Scale insects, Brachiaria, Pasture pests.

Pastures are a fundamental part of the livestock production chain in Brazil, whether native or cultivated, occupying more than 159 million hectares (IBGE 2017). Among the main pests that attack the pastures are spittlebugs, burrower bugs, the chinch bug, caterpillars, and the rhodesgrass mealybug, as well as ants, termites, grasshoppers and Coleoptera larvae. For decades, damage caused by scale insects in pastures has been attributed to the rhodesgrass mealybug, Antonina graminis (Maskell, 1897) (Hemiptera: Pseudococcidae). It was brought under control, however, after the introduction of the parasitoid Neodusmetia sangwani (Subba Rao, 1957) (Hymenoptera: Encyrtidae) in 1967. The appearance of another species of scale insect, causing severe damage to pastures, had not been documented until now.

In an experimental pasture field of Embrapa Beef Cattle $\left(2026^{\prime} 56.4^{\prime \prime}{ }^{\circ} \mathrm{S} 5442^{\prime} 50.9^{\prime \prime} \mathrm{W}\right)$ in Campo Grande, Mato Grosso do Sul, Brazil, in 2018, the presence of armored scale specimens was found in Urochloa leaves, with reinfestations in 2019 and 2020. In these cases, the pasture was formed with the Urochloa hybrid BRS Ipyporã (Urochloa brizantha $\times$ Urochloa ruziziensis), a cultivar that is resistant to another sucking insect, the spittlebugs.

Infestation was detected in the dry season, in mid-August. Grass leaves were then collected by randomly selecting 10 points in the infested area, which covered 0.45 ha. At these points, samples of grass leaves were taken (about 100 leaves per sample) and separated into collections with and without scale insects reaching an average value of $60 \%$ of infested leaves in that area.

From the collections, leaves with armored scale specimens were separated, placed in flasks containing $70 \%$ alcohol for posterior identification. The armored scales were slide-monted flowing the adapted techniques by Wolff (2001) and were identified as Duplachionaspis divergens (Green, 1899) (Hemiptera: Diaspididae) (Fig. 1) according to the morphological characteristics of female adult as described by Green (1899); Takagi (1961); Evans \& Hodges (2007); Yu \& Suh (2012); Monteiro et al. (2019); Normak et al. (2019). The vouchers were deposited in the Reference Collection in The Center for Research in Plant Production Department of Diagnosis and Agricultural Research, Secretariat of Agriculture, Livestock and Irrigation, Porto Alegre, Rio Grande do Sul, Brazil.
Duplachionaspis divergens was described by Green in 1899 as Chionaspis graminis divergens from samples collected on Cymbopogon nardus (L.) Rendle (Poaceae) (= Andropogon nardus), in Sri Lanka. Currently, this diaspidid has been reported attacking 18 genera of grasses (Poaceae) in 18 countries (Garcia Morales et al. 2016). It has been found in sugar cane in India since 1942 and was later also reported in Venezuela, Colombia, United States, Japan, Sri Lanka, Korea, China, Australia, Algeria, Egypt, Taiwan, Thailand, Mexico, and Brazil (Bustillo-Pardey 2013; Pantaleón \& Chinea 2015; Garcia-Morales et al. 2016; Caballero et al. 2017; Monteiro et al. 2019). Other grasses, such as some species of the genera Andropogon, Sorghum, Digitaria, Paspalum, Panicum, Pennisetum, and Setaria, have also been described as a food source for this insect (Evans \& Hodges 2007; Malumphy 2012; Garcia Morales et al. 2016).

In Brazil, this species has until now been found only in sugarcane. It was reported for the first time in March 2018 in sugarcane plants grown in pots inside a greenhouse in the state of São Paulo (Monteiro et al. 2019).

After the initial discovery in a pasture, new infestations causing similar damage were found in other forage grasses in the same experimental station (Embrapa Beef Cattle). Such grasses include Pennisetum purpureum (elephant grass) cvs. Napier, Cameroon, Pioneiro, BRS Canará, BRS Kurumi, and BRS Capiaçu; and Panicum maximum cv. Aruana. It is assumed that such grasses are also host plants for $D$. divergens.

Biology data of this scale insect in sugarcane plants show that the female can oviposit around 130 small white eggs, with an average embryonic period of 8 days. The nymphal phase lasts about 30 days, with nymphs being mobile in their first instar and later settling, where they remain feeding and developing until the adult stage. The male differs from the female in the nymphal stage (at 7 days of development) when wax fringes form on its back and in the adult stage by being winged. The adult females are yellow and covered with a layer of white wax of oval shape, where the eggs are protected until the nymphs hatch. The complete cycle lasts an average of 39 days and can yield nine generations per year (Lastra \& Gomes 1997; Bustillo-Pardey 2013).

The damage that $D$. divergens causes is due to the suction of sap 
on leaves, leading to yellowing and drying of the attacked parts (Fig. 2). The fixation sites are usually on the abaxial surface of the leaves, but in high infestations they can also be found on the stems (Bustillo-Pardey 2013; Pantaleón \& Chinea 2015). In the present study, specimens were found also on the adaxial surface of the leaves.

According to Bustillo-Pardey (2013), a leaf infestation of up to $30 \%$ (one third of the leaf with scale insects) can cause significant losses of sugarcane, more so in soil of low fertility. In the context of national cattle breeding, $D$. divergens has only recently been found in pastures, and the losses have still to be determined. The damage, however, was visibly significant, making this insect a serious threat to meat and milk production systems.
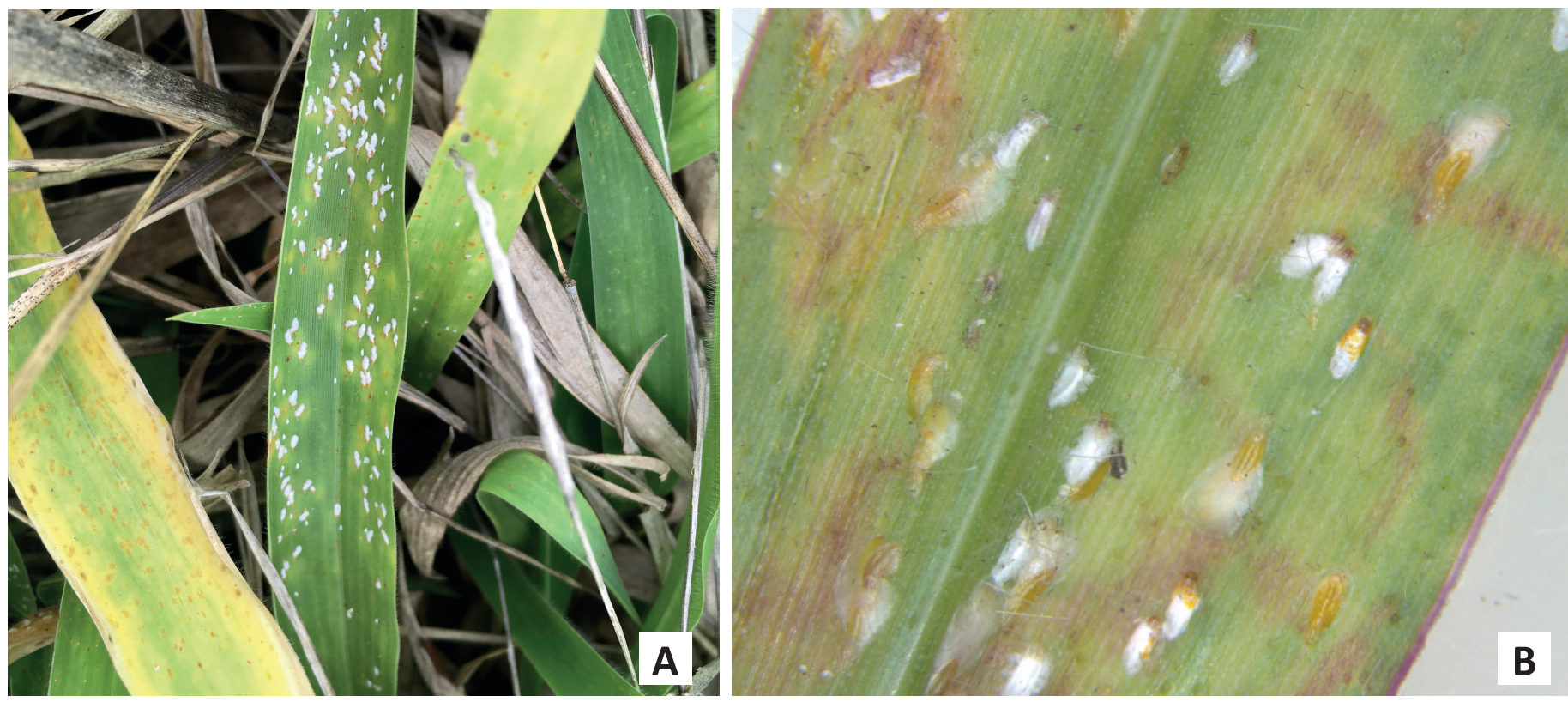

Figure 1. Leaf with scale insects (A) and Duplachionaspis divergens (B)
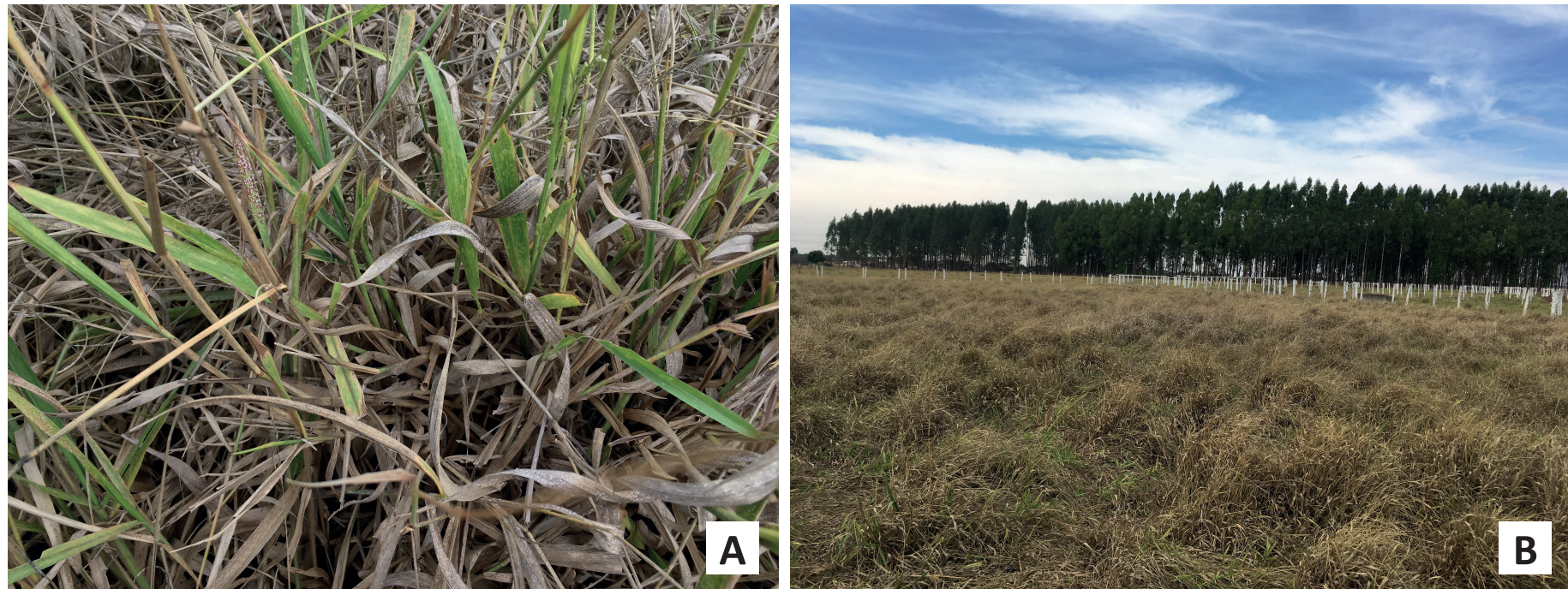

Figure 2. Leaves (A) and pasture area (B) of Urochloa with damage from Duplachionaspis divergens.

\section{Authors' Contributions}

F.Z.V.T. took the pictures ( $1 \mathrm{~A}, 2 \mathrm{~A}$ and $2 \mathrm{~B})$, performed data collection, reviewed the literature and wrote the manuscript; J.R.V. reviewed the literature and wrote the manuscript; R.N.S. performed data collection; B.B.A. performed data collection and take the picture 1B; V.R.S.W. performed species identification and reviewed the manuscript.

\section{References}

Bustillo-Pardey, A. E. (2013) Insectos plaga y organismos benéficos del cultivo de la caña de azúcar en Colombia. Cali: Centro de Investigación de la Caña de Azúcar de Colombia. https://repository. agrosavia.co/handle/20.500.12324/12701. Access on 2.vii.2020.

Caballero, A.; Ramos-Portilla, A. A.; Kondo, T. (2017) Scale insects (Hemiptera: Coccomorpha) on sugarcane in Colombia, with description of a new species of Tillancoccus Ben-Dov (Coccidae). Zootaxa, 4258(5): 490-500. doi: 10.11646/zootaxa.4258.5.6

Evans, G. A.; Hodges, G. S. (2007) Duplachionaspis divergens
(Hemiptera: Diaspididae), a new exotic pest of sugarcane and other grasses in Florida. Florida Entomologist, 90(2): 392-393. doi: 10.1653/0015-4040(2007)90[392:DDHDAN]2.0.CO;2

García Morales, M.; Denno, B. D.; Miller, D. R.; Miller, G. L.; Ben-Dov, Y.; Hardy, N. B. (2016) ScaleNet: a literature-based model of scale insect biology and systematics. United States of America: USDA. http://scalenet.info. Access on 2.vii.2020. doi: 10.1093/database/ bav118

Green, E. E. (1899) Description of a new scale insect of the genus Walkeriana. Annals and Magazine of Natural History, 3: 45-47. doi: 10.1080/00222939908678075

IBGE (2017) Censo Agropecuário. https://censos.ibge.gov. br/agro/2017/templates/censo_agro/resultadosagro/ estabelecimentos.html. Access on 2.vii.2020

Lastra, L. A.; Gomez, L. A. (1997) Observaciones del ciclo de vida de la escama blanca, Duplachionaspis divergens (Green) (Homoptera: Diaspididae) y reconcimiento de enemigos naturales. IV Congreso Colombiano de la Asociación de Técnicos de la Cana de Azúcar, Cali, Colombia, pp 24-26. 
Malumphy, C. (2012) Incursions of Duplachionaspis divergens (Green), an Asian pest of grasses, and D. exalbida (Cockerell), a South African pest of aloe, in Britain (Hemiptera: Diaspididae). Entomologist's Monthly Magazine, 148: 23-30.

Monteiro, G. G.; Wolff, V. R. S.; Peronti, A. L. B. G.; Martinelli, N. M.; Anjos, I. A. (2019) First record of Hemiberlesia musae Takagi \& Yamamoto, 1974 and Duplachionaspis divergens (Green, 1899) (Hemiptera: Diaspididae) on sugarcane in greenhouse in Brazil. Journal of Agriculture Science, 11(2): 392-396. doi: 10.5539/jas. v11n2p392

Normark, B. B.; Okusu, A.; Morse, G. E.; Peterson, D. A.; Itioka, T.; Schneider, S. A. (2019) Phylogeny and classification of armored scale insects (Hemiptera: Coccomorpha: Diaspididae). Zootaxa, 4616: 1-98.

Pantaleón, G. P.; Chinea, A. M. (2015) The armored scale: Duplachionaspis divergens (Green), a new pest of sugarcane detected recently in Mexico. Sugar Journal, 78(5): 15-17.

Takagi, S. (1961) A contribution to the knowledge of the Diaspididini of Japan (Homoptera: Coccoidea) Pt. II. Insecta Matsumurana, 24: 4-42.

Wolff, V. R. S. (2001) Dez espécies novas de Pseudoparlatoria Cockerell, 1892 (Hemiptera, Coccoidea, Diaspididae). [Ten new species of Pseudoparlatoria Cockerell, 1892 (Hemiptera, Coccoidea, Diaspididae).] Arquivos do Instituto Biológico, 68(2): 67-76.

Yu, H. M.; Suh, S. J. (2012) A new record for the genus Duplachionaspis armored scale (Hemiptera: Diaspididae) from Korea. Korean Journal of Applied Entomology, 52: 63-67. 